Hewitt, L. F. (1954). J. gen. Microbiol. 11, 288-299.

\title{
The Effect of certain Antibiotics and other Ghemothera- peutic Agents on Lysogenicity and Virulence Transfer by Bacterial Viruses in Corynebacterium diphtheriae
}

\author{
By L. F. HEWITT \\ Serum Research Institute, Medical Research Council, Carshalton, Surrey
}

SUMMARY: The treatment of bacteria with antibiotics, chemotherapeutic agents or various chemicals influences the nature of the viruses with which the bacteria are infected. In the case of Corynebacterium diphtheriae many strains are infected with two or more distinct kinds of virus. Cultivation of these lysogenic strains in the presence of certain drugs may result in the removal of one of the viruses with a consequent alteration in the characters of the strain. Apart from changes in the host specificity of virus preparations yielded by the treated strains, these viruses may also differ in their capacity to transfer virulence to avirulent strains. For example, one diphtheria strain after treatment with certain antibiotics and chemicals developed the capacity to transfer virulence which it had not originally possessed. An avirulent strain after subcultivation in presence of certain drugs became susceptible to virulence-transfer from virus preparations not able to convey virulence to the parent strain. It appears that in lysogenic bacterial strains infected with two kinds of virus, one of the viruses may be more labile or easily removed than the other. Possibly the easily removable virus may be carried in the cytoplasm of the cell whilst the more stable virus may have some attachment to the nuclear apparatus of the bacterial cell. In one case investigated the stable virus was able to transfer virulence to an avirulent strain, whilst the cytoplasmic virus was not. It appears that there are two distinct mechanisms by which drugs may affect the viruses carried by bacterial strains: (i) by the selection of bacterial variants carrying a certain virus; (ii) by the preferential removal of the more labile viruses and inhibition of their multiplication. The results suggest criteria to be applied to the selection of potential chemotherapeutic agents for treating animal virus infections.

Complications in tracing the effects of bacterial viruses on bacterial variation and evolution were attributed in former communications to the presence of mixtures of viruses in lysogenic bacterial strains (Hewitt, 1954a, b). Further information on this point has now been sought by investigating the effects of various drugs on the nature of the virus preparations yielded by lysogenic strains. In these preliminary studies the substances chosen for study included antibiotics and other chemotherapeutic substances known to have bactericidal or bacteriostatic effects, various metabolic and enzyme poisons, competitive metabolite analogues and other compounds which may inhibit virus multiplication.

\section{METHODS}

The strains of Corynebacterium diphtheriae used, particularly a group of gravis strains, have been described previously (Hewitt, 1954b); the general experimental methods used were as before. Methods of obtaining drug-resistant strains have also been described (Hewitt, 1948 $a, b ; 1950 a, b ; 1952)$. 
Streptomycin was used in the form of the sulphate, crystalline erythromycin base was kindly supplied by Abbott Laboratories and propamidine di-isethionate by Messrs May and Baker. Other drugs were of the purest form obtainable and were sterilized by filtration of the solutions or by heating.

\section{RESULTS}

\section{Effects of treatment with streptomycin}

Growth of the diphtheria strains was inhibited by streptomycin sulphate in a dose of about $1 \mu \mathrm{g} . / \mathrm{ml}$., but after several subcultures in media containing graded dilutions of the antibiotic, resistant cultures were obtained which grew in broth containing $1000 \mu \mathrm{g}$. streptomycin sulphate $/ \mathrm{ml}$. (Hewitt, 1948a). After several further subcultures in streptomycin broth followed by cultivation in plain broth the resistant strains were tested for toxigenicity, virus sensitivity and lysogenicity. The virulence of the resistant strains remained unaltered. Thus the streptomycin-resistant strain $868 \mathrm{~S}$ remained avirulent, like the parent strain $\mathrm{H} 868$, and strains $873 \mathrm{~S}$ and $874 \mathrm{~S}$ remained virulent. The strains $873 \mathrm{~S}$ and $874 \mathrm{~S}$ remained lysogenic but there was a change in virus sensitivity

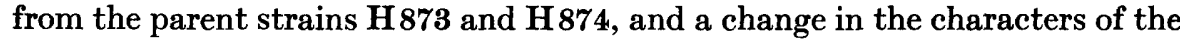
viruses they were carrying. Virus preparations from the resistant and parent strains were obtained by ultraviolet irradiation of broth cultures followed by incubation and filtration through sterile collodion membranes. The behaviour of the strains and viruses is given in Table 1 . It will be seen that $873 \mathrm{~S}$ and $874 \mathrm{~S}$ still carried viruses capable of lysing $\mathrm{H} 868$ but, whereas the virus preparation from the parent strain $\mathbf{H 8 7 4}$ lysed $\mathbf{H 8 7 3}$, the viruses from the streptomycin-resistant strain $874 \mathrm{~S}$ did not. This suggests that the parent strain $\mathbf{H ~ 8 7 4}$ was carrying two viruses, only one of which was capable of lysing

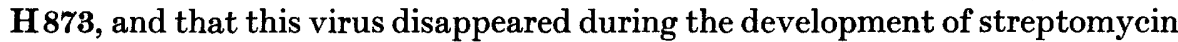
resistance. Confirmation of this follows from the fact that the virus preparation obtained from the parent strain $\mathbf{H ~ 8 7 4}$ lysed the corresponding streptomycinresistant strain $874 \mathrm{~S}$. The streptomycin-resistant strain had lost one of the viruses (the one attacking $\mathbf{H 8 7 3}$ ), and being no longer symbiotically infected with this virus was now susceptible to its action. Inspection of Table 1 fails to reveal any differences in the virus susceptibility of strain $\mathrm{H} 868$ when it is

Table 1. Effect of streptomycin resistance of strains of Corynebacterium diphtheriae on lysogenicity

\begin{tabular}{|c|c|c|c|c|c|c|}
\hline \multirow{2}{*}{$\begin{array}{l}\text { Source of } \\
\text { virus } \\
\text { preparation } \\
\text { (strain of } \\
\text { C. diphtheriae) }\end{array}$} & \multicolumn{6}{|c|}{ Susceptible strains of $C$. diphtheriae } \\
\hline & H868 & $868 \mathrm{~S}$ & $\begin{array}{c}\text { H873 } \\
\text { Lysis }\end{array}$ & $\begin{array}{l}\text { 873S } \\
\text { luced }\end{array}$ & H874 & $874 S$ \\
\hline H873 & + & + & $\mathbf{0}$ & $\mathbf{0}$ & + & + \\
\hline $873 \mathrm{~S}$ & + & + & $\mathbf{0}$ & $\mathbf{0}$ & + & + \\
\hline H874 & + & + & + & $\mathbf{0}$ & $\mathbf{0}$ & + \\
\hline $874 S$ & + & + & $\mathbf{0}$ & $\mathbf{0}$ & $\mathbf{0}$ & $\mathbf{0}$ \\
\hline
\end{tabular}

$+=$ marked lysis on serum agar plate $0=$ no visible lysis. 
made streptomycin-resistant and there are no apparent differences in the host specificity of the viruses carried by $\mathrm{H873}$ and the streptomycin-resistant variant $873 \mathrm{~S}$; but alterations have, however, been produced, as shown in the next section.

\section{Effect of streptomycin resistance on virulence transfer}

Viruses from strain $\mathrm{H} 874$, convert the avirulent strain $\mathrm{H} 868$ to virulence, whilst $\mathrm{H} 873$ viruses do not (Hewitt, 1954a, $b$ ). In the next series of experiments virus preparations from both the parent strains and the streptomycinresistant variants were added to the avirulent strain $\mathrm{H} 868$ and the streptomycinresistant $868 \mathrm{~S}$. The virus-resistant strains which grew out were subcultured in broth to rid them of free virus particles and tested for toxigenicity. From the results given in Table 2 it will be seen that viruses from the strains $\mathbf{H} 874$ and $874 \mathrm{~S}$ rendered both $\mathrm{H} 868$ and $868 \mathrm{~S}$ fully toxigenic. On the other hand, there was a change in the behaviour of $\mathrm{H} 873$ viruses when the bacterial strain had been made streptomycin-resistant. Viruses from the parent strain $\mathbf{H} 873$ failed to convey toxigenicity to $\mathrm{H868}$ or $868 \mathrm{~S}$, but viruses from the streptomycin-resistant strain $873 \mathrm{~S}$ converted strain $868 \mathrm{~S}$ to full toxigenicity. Only a trace of toxigenicity was conveyed to $\mathrm{H} 868$ by $873 \mathrm{~S}$ viruses.

Table 2. Effect of streptomycin resistance of strains of Corynebacterium diphtheriae on toxigenicity transfer by virus preparations

$\begin{array}{ccc}\begin{array}{c}\text { Virus } \\ \text { from } \\ \text { (strain of }\end{array} & \begin{array}{c}\text { H868 } \\ \text { Toxigenicity (units toxin/ml.) }\end{array} \\ \text { Ciphtheriae) } \\ \text { H873 } & \overbrace{0}^{\text {Virus-resistant strain from }} \\ \text { 873S } & 0.008 & 0 \\ \text { H874 } & 0.6 & 1.5 \\ 874 \mathrm{~S} & 1.3 & 0.6 \\ & & 1.4\end{array}$

The explanation of the results from experiments in this and preceding communications is that the parent strains $\mathrm{H} 873$ and $\mathrm{H} 874$ each carry two distinct viruses and $\mathbf{H} 868$ one virus. During the development of streptomycin resistance, bacterial cells are selected which have each lost one type of virus, so that $873 \mathrm{~S}$ and $874 \mathrm{~S}$ are now each carrying only one type of virus and $868 \mathrm{~S}$ is no longer lysogenic. The viruses carried by the parent strain $\mathrm{H} 874$ may be designated $874,1\left(t^{+}\right)$and 874,2 . Virus $874,1\left(t^{+}\right)$is dominant, as shown in the previous communication, and capable of transferring toxigenicity $\left(t^{+}\right)$to the avirulent strain $\mathbf{H} 868$. Virus 874,2 , is incapable of transferring toxigenicity to the avirulent strain but it is capable of lysing strain H873, unlike virus 874, $1\left(t^{+}\right)$. Since both the parent strain $\mathrm{H} 874$ and $874 \mathrm{~S}$ carry virus $874,1\left(t^{+}\right)$both strains yield virus preparations which transfer virulence to $\mathrm{H} 868$, but only $\mathrm{H} 874$ carries virus 874,2 , hence the resistant strain $874 \mathrm{~S}$ does not yield virus which lyses $\mathrm{H873}$ and is indeed itself susceptible to lysis by 874,2 . In the case of strain $\mathbf{H 8 7 3}$, the dominant virus 
873,1 , is incapable of transferring toxigenicity to the avirulent strain, but removal of this virus allows the weaker virus $873,2\left(t^{+}\right)$to infect other strains, and this virus is capable of conveying toxigenicity to the susceptible avirulent strain $868 \mathrm{~S}$. The strain $\mathrm{H} 868$ appears to be carrying a virus which hinders the conveyance of toxigenicity to the strain by the weak virus $873,2\left(t^{+}\right)$but not by the dominant virus $874,1\left(t^{+}\right)$. Removal of the virus yields strain $868 \mathrm{~S}$ which is no longer lysogenic, and there is therefore no hindrance to toxigenicity transfer even by the weak virus $873,2\left(t^{+}\right)$. These conclusions are summarized in Table 3.

Table 3. Viruses carried by lysogenic strains of Corynebacterium diphtheriae

\begin{tabular}{|c|c|c|}
\hline $\begin{array}{l}\text { Strain of } \\
\text { C. diphtheriae }\end{array}$ & $\begin{array}{l}\text { Viruses } \\
\text { carried }\end{array}$ & $\begin{array}{l}\text { Dominant } \\
\text { virus }\end{array}$ \\
\hline H868 & 868,1 & 868,1 \\
\hline $868 \mathrm{~S}$ & 0 & 0 \\
\hline H873 & 873,$1 ; 873,2\left(t^{+}\right)$ & 873,1 \\
\hline $873 \mathrm{~S}$ & $873,2\left(t^{+}\right)$ & $873,2\left(t^{+}\right)$ \\
\hline H 874 & $874,1\left(t^{+}\right) ; 874,2$ & $874,1\left(t^{+}\right)$ \\
\hline $874 S$ & $874,1\left(t^{+}\right)$ & $874,1\left(t^{+}\right)$ \\
\hline
\end{tabular}

\section{Effect of various chemotherapeutic agents and other compounds}

Some insight into the mechanisms by which streptomycin affected the viruses carried by lysogenic strains may be gained by studying the effects of various other substances. In each case strains were subcultured in broth containing serial dilutions of the given compound and subcultures were made from the culture which contained the highest concentration of the compound in which bacterial growth occurred. These serial subcultures were continued from 6 to 12 times and some increases in tolerance to the compounds were observed; in no case was the degree of resistance developed comparable to that obtained with streptomycin. Approximate inhibitory concentrations of the drugs in the case of various diphtheria strains are summarized in Table 4.

Erythromycin was found to be extremely inhibitory to diphtheria cultures, and the increased resistance developed when the organisms were subcultured in presence of this compound was comparatively slight, as observed with penicillin, and not marked as with streptomycin (Hewitt, 1948a). The increased resistance to propamidine was also of the same order as that observed previously (Hewitt, 1948b). It is perhaps of interest that sodium arsenite was much more inhibitory to diphtheria bacilli than was sodium azide, and that potassium cyanide and 2:4-dinitrophenol, although metabolic poisons, were relatively non-toxic.

The toxigenicities of the strains, derived from strains H868, H873 and $\mathbf{H ~ 8 7 4}$, and by subcultivation in the presence of the various compounds listed in Table 4 were tested by growing cultures in standardized broth and titrating the culture filtrates against standard diphtheria antitoxin by intracutaneous injection in albino guinea-pigs. In no case was there any appreciable change 
Table 4. Development of resistance to certain compounds in strains of Corynebacterium diphtheriae

$\begin{array}{lcc}\begin{array}{c}\text { Compound } \\ \text { used }\end{array} & \begin{array}{c}\text { Initial } \\ \text { inhibitory } \\ \text { dose } \\ (\mu \mathrm{g} \cdot / \mathrm{ml} .)\end{array} & \begin{array}{c}\text { Increased } \\ \text { tolerance } \\ \text { factor }\end{array} \\ \begin{array}{l}\text { Streptomycin } \\ \text { Erythromycin }\end{array} & 1 & 1000 \\ \text { Propamidine } & 0 \cdot 1 & 4 \\ \text { di-isethionate } & 5 & 4 \\ \text { Euflavine } & & \\ \text { Thiouracil } & 10 & 4 \\ \text { Barbituric acid } & >1000 & 0 \\ \text { Arsenite } & >1000 & 0 \\ \text { Azide } & 50 & 0 \\ \text { Cobaltous chloride } & 500 & 0 \\ \text { Cupric sulphate } & 200 & 0 \\ \text { Cyanide } & 200 & 0 \\ \text { 2:4-Dinitrophenol } & 200 & 2 \\ & 500 & 0\end{array}$

in toxigenicity except for a decrease in the case of the streptomycin-resistant strains and in the strain from $\mathbf{H 8 7 4}$ treated with cyanide.

Each drug-resistant strain was tested for its sensitivity to various virus preparations. The lysogenic viruses carried by the strains were investigated by ultraviolet irradiation of the cultures and testing the lytic activities of the sterile virus filtrates. There were no marked alterations of virus sensitivity of the strains $\mathrm{H} 868$ and $\mathrm{H} 873$ and the lysogenic viruses carried by these strains showed no change in host specificity after being treated with the various compounds listed in Table 4. The only alterations in virus sensitivity and in the nature of the viruses carried by strain H874 were those produced by streptomycin and already mentioned (Table 5). There were, nevertheless, changes in the characters of some of the lysogenic viruses as shown in the next section.

Table 5. Lysogenic viruses carried by drug-resistant strains of Corynebacterium diphtheriae derived from strain $\mathbf{H} \mathbf{8 7 4}$

\begin{tabular}{|c|c|c|c|c|}
\hline \multirow[b]{2}{*}{$\begin{array}{l}\text { Virus derived from } \\
\text { strain resistant } \\
\text { to drug }\end{array}$} & \multicolumn{4}{|c|}{ Strain of C. diphtheriae } \\
\hline & H868 & $\begin{array}{c}\text { H873 } \\
\text { Lysis }\end{array}$ & $\begin{array}{l}\text { H874 } \\
\text { uced }\end{array}$ & 874 \\
\hline None & + & + & 0 & + \\
\hline Streptomycin & + & $\mathbf{0}$ & $\mathbf{0}$ & $\mathbf{0}$ \\
\hline Erythromycin & + & + & $\mathbf{0}$ & + \\
\hline Propamidine & + & + & $\mathbf{0}$ & + \\
\hline Euflavine & + & + & $\mathbf{0}$ & + \\
\hline Thiouracil & + & + & $\mathbf{0}$ & + \\
\hline Barbituric acid & + & + & $\mathbf{0}$ & + \\
\hline Arsenite & + & + & $\mathbf{0}$ & + \\
\hline Axide & + & + & $\mathbf{0}$ & + \\
\hline Cobalt & + & + & $\mathbf{0}$ & + \\
\hline Copper & + & + & 0 & + \\
\hline Cyanide & + & + & $\mathbf{0}$ & + \\
\hline 2:4-Dinitrophenol & + & + & 0 & + \\
\hline
\end{tabular}




\section{Virulence transfer from drug-resistant strains}

The sterile virus filtrates obtained after ultraviolet irradiation of the drugresistant strains were tested for their virulence-transferring activity by adding them to the susceptible avirulent strain $\mathbf{H 8 6 8}$. The virus-resistant strains which grew out after incubation overnight were subcultured twice in broth to ensure virus 'homogenization' (Hewitt, 1954b) before their toxigenicity was tested. The results are summarized in Table 6. It will be seen that viruses from the drug-resistant strains derived from $\mathrm{H} 874$, still conveyed toxigenicity whilst those from $\mathrm{H} 873$ still failed to convey toxigenicity except for the slight toxigenicity transferred by viruses from the streptomycin-resistant strain.

\section{Table 6. Toxigenicity transfer by viruses from drug-resistant strains of} Corynebacterium diphtheriae to avirulent strain $\mathbf{H} 868$

\begin{tabular}{|c|c|c|}
\hline & H873 & $\mathbf{H 8 7 4}$ \\
\hline $\begin{array}{c}\text { Strain } \\
\text { resistance }\end{array}$ & \multicolumn{2}{|c|}{ Units toxin/ml. } \\
\hline None & & $0 \cdot 6$ \\
\hline Streptomycin & 0.008 & $1 \cdot 3$ \\
\hline $\begin{array}{l}\text { Propamidine } \\
\text { di-isethionate }\end{array}$ & 0 & 0.5 \\
\hline Euflavine & 0 & 0.9 \\
\hline Thiouracil & $\mathbf{0}$ & $0 \cdot 4$ \\
\hline
\end{tabular}

Table 7. Toxigenicity transfer to avirulent strain $868 \mathrm{~S}$ of Corynebacterium diphtheriae

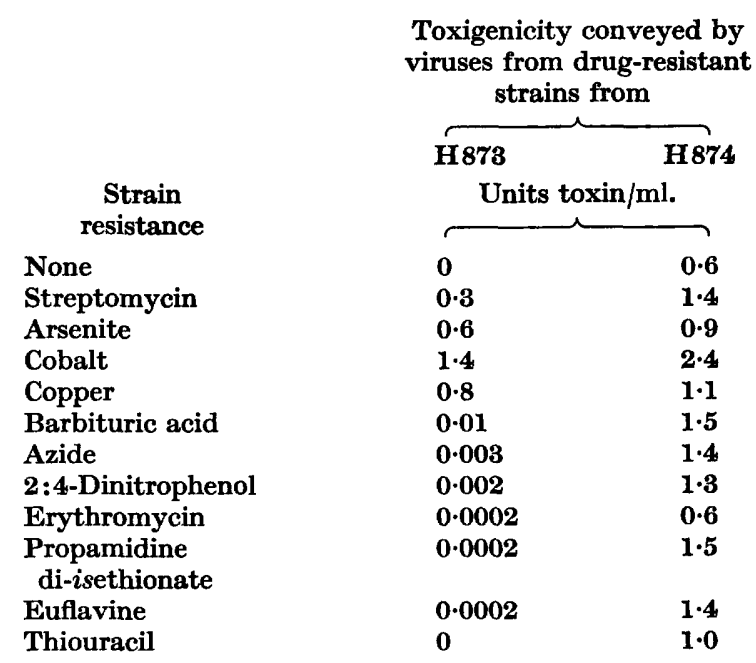

Different results, however, were obtained when the viruses were added to the streptomycin-resistant avirulent strain $868 \mathrm{~S}$; the results are summarized in Table 7. It will be seen that the $\mathbf{H ~ 8 7 4}$ drug-resistant strains yielded viruses 
which conveyed toxigenicity as before, but the viruses from some of the H873 drug-resistant strains were also capable of transferring toxigenicity. H873 strains made resistant to arsenite, copper or cobalt as well as streptomycin converted the avirulent strain to full toxigenicity. Slight toxigenicity, in decreasing degree, was also conveyed by the viruses from $\mathrm{H873}$ strains treated with barbituric acid, sodium azide, 2:4-dinitrophenol, erythromycin, propamidine di-isethionate or euflavine. In each of these cases the compound had exerted an effect, in varying degree, of suppressing the non-virulenceconveying virus carried by $\mathbf{H 8 7 3}$ and thus enabled the virulence-conveying virus $2\left(t^{+}\right)$to become dominant and effective.

\section{Converted virulent strain}

It was thought possible that an avirulent strain recently converted to virulence by treatment with a virus might be more susceptible to alteration or removal of its lysogenic virus. Strain $\mathrm{H} 868$ after treatment with viruses from H874 yielded a fully virulent and toxigenic strain 868R874. After frequent subculture in broth and on Loeffler slopes it was grown in streptomycin broth. After nine subcultures in this streptomycin broth its resistance to streptomycin had increased 1000 times. The streptomycin-resistant strain remained virulent and toxigenic $(0 \cdot 3$ unit toxin $/ \mathrm{ml}$.) and when irradiated with ultraviolet light it liberated virus which was filtered through a collodion membrane and added to the avirulent strain $\mathbf{H 8 6 8}$. The virus-resistant strain which grew out was virulent and toxigenic (1.4. units toxin/ml.) The virus also conveyed virulence and toxigenicity $(0.6$ unit toxin $/ \mathrm{ml}$.) to the streptomycinresistant avirulent strain $\mathbf{8 6 8 \mathrm { S }}$.

The converted avirulent strain ( $868 \mathrm{R} \mathrm{874}$ ) was also subcultured in increasing concentrations of propamidine di-isethionate or thiouracil. In each case the toxigenicity was maintained (1.3 and $2 \cdot 0$ units toxin/ml. respectively) and the strains remained lysogenic. Thus in converting it to virulence the virus had formed a stable symbiotic infection of the avirulent strain and neither the lysogenicity nor the toxigenicity could be removed readily.

\section{DISCUSSION}

Streptomycin-resistant strains of Corynebacterium diphtheriae derived from lysogenic bacteria differ from the parent strains not only in antibiotic resistance but also in the viruses they are carrying. As a result of these experiments and others previously reported (Hewitt, 1954a, $a$ ) it is concluded that two virulent gravis strains of $C$. diphtheriae were each carrying two distinct viruses. In each case one of the viruses $\left(t^{+}\right)$was capable of transferring virulence and toxigenicity to a susceptible avirulent strain, whilst the other virus $(n)$ was not. In one strain, $\mathrm{H} \mathrm{874}$, the toxigenicity-transferring virus $t^{+}$was dominant whilst in the other strain $\mathbf{H 8 7 3}$ the virus incapable of transferring virulence, virus $n$, predominated. When the virus preparation from $\mathrm{H874}$ was added to the avirulent strain the virus-resistant culture which grew out was fully virulent and toxigenic, whilst the resistant culture obtained by the action of 
the viruses from $\mathbf{H 8 7 3}$ on the avirulent strain remained completely avirulent and non-toxigenic, although it had been rendered lysogenic with respect to the infecting virus. On the other hand, when the streptomycin-resistant cultures $873 \mathrm{~S}$ and $874 \mathrm{~S}$ derived from the parent strains were examined they were both found to have lost the $n$ virus but to have retained the virulence-transferring $t^{+}$virus. This had little apparent effect on the $\mathbf{H} 874$ viruses since the $t^{+}$virus had been dominant originally but, in the case of strain $\mathrm{H} 873$ the removal of the $n$ virus allowed the $t^{+}$virus to exert its effect and $873 \mathrm{~S}$ viruses were capable of transferring virulence and toxigenicity to the susceptible avirulent strain, unlike the parent $\mathbf{H} 873$ viruses. The $t^{+}$and $n$ viruses from $\mathrm{H} 874$ differ in host specificity since only the $n$ virus is capable of lysing strain $\mathbf{H ~ 8 7 3 . ~ T h e ~ s t r e p t o - ~}$ mycin-resistant $874 \mathrm{~S}$ strain, having lost its $n$ virus, is now susceptible to lysis by viruses from the parent strain, which is infected with both $t^{+}$and $n$ viruses. From their behaviour it appears that the $t^{+}$and $n$ viruses of strain $\mathbf{H} 873$ differ from those of strain $\mathbf{H 8 7 4}$. In the case of the avirulent strain $\mathrm{H} 868$ the development of streptomycin resistance is accompanied by increased susceptibility to conversion to virulence. The parent strain $\mathrm{H} 868$ is rendered fully virulent and toxigenic by virus preparations which contain the dominant $t^{+}$ virus from $\mathrm{H} \mathrm{874}$, but not by the 'recessive' $t^{+}$virus from $\mathrm{H873}$ strains. The streptomycin-resistant avirulent strain $868 \mathrm{~S}$ is, however, rendered fully virulent and toxigenic by the $t^{+}$virus from $\mathrm{H} 873$ strains made resistant to streptomycin and various other compounds. Presumably H868 itself carries a virus which prevents transfer of virulence from 873 strains by the relatively ineffective $873 t^{+}$virus.

Other compounds besides streptomycin affect the viruses carried by lysogenic strains. In particular, arsenite, cobalt and copper salts are particularly effective in removing the dominant $n$ virus from $\mathrm{H873}$ so that the remaining $t^{+}$virus is able to transfer virulence to the susceptible avirulent strain.

In seeking an explanation of the fact that it is always the $n$ virus which is removed from the lysogenic strains by drug treatment it is perhaps significant to note that the more firmly established $t^{+}$virus is the one capable of transferring toxigenicity to susceptible strains. The virulence or toxigenicity appears to be a genetic property permanently transferred to the strain and inherited by the daughter cells. It is possible, therefore, that the firmly established $t^{+}$ viruses are attached to the chromosomal or nuclear structures of the bacterial cell, whilst the relatively labile $n$ viruses may be free in the cell cytoplasm. It may be that cases in the literature of loss of viruses from lysogenic strains (den Dooren de Jong, 1931; Clarke, 1952) may have occurred in the case of purely cytoplasmic viruses whilst the more firmly attached viruses with which attempts at removal have failed may be attached to the cellular genetic structure.

Although lysogenic bacteria generally transmit symbiotic viruses to all their progeny it is by no means certain that each of the infecting viruses forms part of the nuclear structure of the host bacterium. When the bacterial cell divides the viruses firmly attached to the nuclear structure would be transmitted to the progeny in indefinite series unless there was a change in the 
genetic structure of the cell corresponding to a mutation. In the case of viruses purely cytoplasmic in location transmission to the daughter cells would be much more haphazard and an occasional daughter cell would occur devoid of this particular type of virus.

Further evidence has accumulated, from the experiments reported in the present communication, on the mechanisms by which bacterial viruses may control bacterial variation and evolution. In particular it would seem that symbiotic viruses differ in their firmness of union with the bacterial cell; in the cases now studied the firmly attached viruses alone seem capable of transferring genetic properties to another bacterium. A further point concerns the dominance of certain viruses over others, but the dominant virus in a lysogenic bacterium is not necessarily the firmly attached virus; in one strain the more 'labile' virus predominated in its influence over the firmly attached 'nuclear' virus, whilst in another the 'nuclear' virus was dominant.

Bacterial viruses may be used for screening and selecting compounds for their potential value in the treatment of animal virus infections. It seems possible that effects in inhibiting bacterial lysis may be comparable to the prophylactic use of drugs for protection against virus infections. For the treatment of established animal virus infections the comparable phenomenon in the case of bacterial viruses is the 'cure' of lysogeny and the removal of lysogenic viruses. It may well be that, just as with the bacterial viruses, certain animal viruses may form more stable infections of their host cell than do other viruses. Eventually there may prove to be considerable differences in the efficacy of chemotherapy in different virus diseases for this reason.

Although streptomycin proved most successful in affecting the viruses carried by the lysogenic strains it is by no means certain that this reflects any direct activity against the viruses themselves. Streptomycin had no inhibitory effect on bacterial lysis by viruses. In the development of streptomycinresistant strains a selection of bacterial variants had occurred and it may well be that the streptomycin-resistant strains differed from the parent strains mainly because the variants selected carried different virus combinations from the parent and not because the streptomycin had any marked direct effect on the viruses.

The mechanism by which streptomycin might be expected to select bacterial variants symbiotically infected with viruses attached to the nucleus but devoid of 'cytoplasmic' viruses may be visualized as follows. As already mentioned, in the case of the progeny of a bacterial cell infected with both 'nuclear' and 'cytoplasmic' viruses, all the daughter cells continue to carry the viruses firmly attached to the nucleus but an occasional daughter cell may be devoid of viruses present in the cytoplasm of the parent cell. A selective agent such as streptomycin which selects only one bacterial cell out of many million could not be expected to affect a virus attached to the bacterial nucleus but might well select for survival a cell devoid of the cytoplasmic virus infection. The streptomycin-resistant culture derived from this variant cell would then be devoid of the cytoplasmic virus. In the case of the other compounds tested there had not been the thousandfold increase in resistance, as 
with streptomycin, and hence not so narrow a selection of bacterial variants. In these other cases, therefore, the results may have been due to a more direct effect of the given compound on the virus infection.

It is interesting in this connexion to note that although Smadel, Jackson \& Gauld (1947) found streptomycin of value against some rickettsial infections it has no effect on certain other virus diseases (Hamre \& Rake, 1947). Although erythromycin has high bactericidal activity against diphtheria bacilli, it has little action on the symbiotic viruses; it did not give rise to highly resistant cultures, as did streptomycin, and hence did not select bacterial variants which carried different viruses. Hobson (1954) found that erythromycin did not affect the lysogenic pattern of staphylococci. Acridines are of limited value in some virus infections (Fitzgerald \& Lee, 1946; Green, Rasmussen \& Smadel, 1946; Hurst, 1948; Foster, 1948; Bourke, Robbins \& Smith, 1952; Takemoto, Robbins \& Smith, 1954). DeMars (1953) found that proflavine effected mutagenesis of viruses active against Escherichia coli; some compounds which induce the liberation of viruses from bacterial cells are also carcinogenic (Boyland, 1952).

Irwin \& Irwin (1954) reported that an acridine compound reacted with nucleic acids; in the present experiments euflavine had only a very slight effect in suppressing one of the bacterial viruses. Propamidine di-isethionate had only a slight effect on the lysogenic viruses of diphtheria, in accord with the results of Bourke et al. (1952) who found only a slight effect on lysis of Escherichia coli. In the case of purine and pyrimidine analogues Thompson, Price, Minton, Falco \& Hitchings (1951) found some protection against vaccinia virus by phenoxythiouracil; Commoner \& Mercer (1952), Jeener (1954), and Bawden \& Kassanis (1954) found that thiouracil influenced some plant virus infections, but Matthews (1953) reported no effect. In the present work thiouracil had no effect on lysogenic diphtheria viruses; barbituric acid had a slight effect.

The other compounds investigated were chosen on account of their known effects on various bacterial enzymes and metabolic systems. Arsenite inhibits oxidative decarboxylation in the citric acid cycle and it was effective in ridding lysogenic diphtheria strains of one of the viruses carried. Azide and cyanide interfere with catalase activity and hence might enable peroxide produced in cellular metabolism to accumulate and to liberate lysogenic viruses, but the effect on lysogenic viruses was slight. Cobalt and copper salts may also lead to peroxide accumulation since thiol (sulphydryl) compounds yield peroxide by auto-oxidation in the presence of traces of these metallic ions. It is perhaps significant, therefore, that both cobalt and copper salts had a marked effect in removing a lysogenic virus from the diphtheria strains used here. 2:4-Dinitrophenol (DNP) causes an uncoupling of oxidative phosphorylation and might be expected to affect the synthesis of the nucleic acids of viruses. Both Heagy (1950) and Czekalowski (1952) found that DNP did inhibit certain bacterial viruses; in the present experiments it had only a very slight effect on the lysogenic diphtheria viruses. 


\section{REFERENCES}

Bawden, F. C. \& Kassanis, B. (1954). Some effects of thiouracil on virus-infected plants. J. gen. Microbiol. 10, 160.

Bourke, A. R., Robbins, M. L. \& Smith, P. K. (1952). Studies on the chemical inhibition of T2 $r+$ bacteriophage. J. Immunol. 69, 75 .

Boyland, E. (1952). Different types of carcinogens and their possible modes of action: a review. Cancer Res. 12, 177.

Clarke, N. A. (1952). Studies on the host-virus relationship in a lysogenic strain of Bacillus megatherium. II. The growth of Bacillus megatherium in synthetic medium. J. Bact. 63, 187.

Commoner, B. \& Mercer, F. (1952). The effect of thiouracil on the rate of tobacco mosaic virus biosynthesis. Arch. Biochem. Biophys. 35, 278.

Czekalowski, J. W. (1952). Studies on the reproduction of bacterial viruses. II. Effect of enzyme-inhibition on the multiplication of the coliphage T2. Brit. J. exp. Path. 33, 57.

DeMars, R. I. (1953). Chemical mutagenesis in bacteriophage T2. Nature, Lond. 172, 964.

Dooren DE Jong, L. E. den (1931). Studien über Bakteriophagie. III. Ǔber Bac. undulatus nov.spec. und den darin anwesenden Bakteriophagen. Z Zbl. Bakt. (Abt. 1), 122, 277.

Fitzgerald, R. J. \& Lee, M. E. (1946). Studies on bacterial viruses. II. Observations on the mode of action of acridines in inhibiting lysis of virus-infected bacteria. J. Immunol. 52, 127.

Foster, R. A. C. (1948). An analysis of the action of proflavine on bacteriophage growth. J. gen. Physiol. 22, 365.

Green, R. H., Rasmussen, A. F. Jr. \& Smadel, J. E. (1946). Chemoprophylaxis of experimental influenza in eggs. Publ. Hlth Rep. 61, 1401.

Hamre, D. \& Rake, G. (1947). Studies on lymphogranuloma venereum; action of some antibiotic substances and sulphonamides in vivo upon agents of feline pneumonitis and lymphogranuloma venereum. $J$. infect. Dis. 81, 175.

HeAGy, F. C. (1950). Effect of 2: 4-dinitrophenol and phage T2 on Escherichia coli B. J. Bact. 59, 367.

Hewits, L. F. (1948a). Protection by streptomycin, penicillin and licheniformin against $C$. diphtheriae infections. Brit. J. exp. Path. 29, 289.

HewitT, L. F. (1948b). Effect of chemotherapeutic agents on C. diphtheriae, with special reference to the diamidines. Brit. J. exp. Path. 29, 447.

HewITT, L. F. (1950 $a$ ). A simple inoculation rack and modified technique for rapid subculturing and antibiotic testing. J. clin. Path. 3, 372.

Hewirt, L. F. (1950b). Use of antibiotics in the treatment of experimental diphtheria infections. Brit. J. exp. Path. 31, 597.

Hewite, L. F. (1952). Oral treatment of experimental diphtheria infections. Brit. J. exp. Path. 33, 217.

HewITT, L. F. (1954a). Autoadaptation of bacterial viruses and its effect on bacterial variation and evolution. J. gen. Microbiol. 11, 261.

Hewit, L. F. (1954b). Mechanism of virulence transfer by bacterial viruses. J. gen. Microbiol. 11, 272.

Hobson, D. (1954). Activity of erythromycin against Staphylococcus aureus. Brit. med. J. i, 236.

Hurst, E. W. (1948). Nitroakridin 3583; compound possessing chemotherapeutic activity against viruses of psittacosis and lymphogranuloma venereum. Brit. J. Pharmacol. 3, 181.

InwIN, J. L. \& Inwin, E. M. (1954). The interaction of a 9-aminoacridine derivative with nucleic acids and nucleo-proteins. J. biol. Chem. 206, 39. 
JEENER, R. (1954). Influence of thiouracil incorporation in the ribonucleic acid moiety of tobacco mosaic virus on its multiplication. Biochem. biophys. Acta, $13,148$.

Matrhews, R. E. F. (1953). Chemotherapy and plant viruses. J. gen. Microbiol. 8, $27 \%$.

Smadel, J. E., JaCkson, E. B. \& Gauld, R. L. (1947). Factors influencing growth of rickettsiae; rickettsiastatic effect of streptomycin in experimental infections. J. Immunol. 57, 273.

TAkemoto, K. K., Robins, M. L. \& Smith, P. K. (1954). The experimental chemotherapy of influenza viruses. J. Immunol. 72, 139.

Thompson, R. L., Price, M., Minton, S. A., Falco, E. A. \& Hitchings, G. H. (1951). Protection of mice against the vaccinia virus by the administration of phenoxythiouracils. J. Immunol. 67, 483.

(Received 14 May 1954) 